\title{
The Foundations of Godwinian Impartiality
}

\author{
ROBERT LAMB
}

University of Exeter

\begin{abstract}
William Godwin is often cited in contemporary philosophical discussions of ethical impartiality, within which he functions as a sort of shorthand for a particularly crude and extreme act-utilitarianism, one that contains no foundational commitments other than the maximizing of some conception of the general good. This article offers a reinterpretation of Godwin's argument, by focusing closely on the ambiguous nature of its justificatory foundations. Although utilitarian political theories seem to have two possible justifications available to them - egalitarian and teleological - there has been little effort to establish which one of them Godwin's argument for impartiality relies on. This problem becomes more complicated when it is acknowledged that Godwin actually provides two different justifications for impartiality, only one of which is consequentialist. The other seems to make a case based on the recognition of moral worth and virtue. This is something confirmed through analysis of Godwin's writings on equality and suggests his political theory is more complex than most philosophers are willing to admit.
\end{abstract}

It is perhaps surprising that the radical philosopher William Godwin, whose popularity peaked and dwindled in the very last years of the eighteenth century, is regularly cited in current philosophical discussions about ethical impartiality. Within these discussions, Godwin usually functions as a sort of shorthand for a particularly extreme and crude form of act-utilitarianism, one that seems to have no foundational principles other than a commitment to maximizing some conception of the general good. The purpose of this article is to offer a reinterpretation of Godwin's argument for impartiality - contained in his 'famous fire cause' - by focusing closely on the ambiguous nature of its justificatory foundations.

Utilitarian political theories can be justified in two different ways: on the one hand, they can emerge from a foundational commitment to 'equal consideration of interests'; and on the other, they can be teleological or perfectionist. My contention is that in his defence of impartiality, Godwin invokes both of these justifications for his utilitarian argument, but that it is remarkably unclear which one has the key justificatory role. Though both egalitarian and teleological interpretations of his argument seem initially plausible, both have problems. Moreover, what seems like a straightforward conflict between two rival utilitarian justifications becomes more complicated once it is recognized that Godwin actually gives two different reasons for acting impartially. Only one of these reasons is clearly utilitarian. The other 
has markedly different roots and seems to make the case for recognizing moral worth or virtue on non-consequentialist grounds.

This almost universally ignored aspect of Godwin's utilitarianism has a dual significance. On the one hand, his argument for impartiality parallels that advanced by John Stuart Mill, perhaps indicating that this issue of justificatory ambiguity has a wider resonance for utilitarianism as a whole. On the other, Godwin's utilitarianism emerges as far more complex than contemporary theorists are usually willing to admit, adding further credence to Brian Barry's observation that 'to some degree ... the "Godwin" in philosophical currency is an invention'. ${ }^{1}$

There seem to be two possible justifications for any version of utilitarianism. As Will Kymlicka notes, the first is a commitment to 'equal consideration of interests', encapsulated by the dictum, famously attributed to Bentham by Mill, 'everybody to count for one, nobody for more than one.' ${ }^{2}$ This approach takes the view that the welfare of each individual is of equal importance and that the best method of recognizing this equality is to ensure that everyone gets an equal standing in the utilitarian calculus. Therefore, according to this view, 'the requirement that we maximize utility is entirely derived from the prior requirement to treat people with equal consideration'. ${ }^{3}$

Kymlicka contrasts this egalitarian justification with the view of utilitarianism as a 'teleological' doctrine. This teleological interpretation, invoked by (among others) John Rawls, considers our moral obligations to be concerned solely with the promotion of a predefined good: 'not with persons, but with states of affairs'. ${ }^{4}$ Thus, an act (or rule) is deemed morally right if it promotes such a good. In order to show that the two justifications cannot be coherently run together, Kymlicka turns to Derek Parfit's much-discussed argument concerning the ethical issues raised by questions of human population. The 'Repugnant Conclusion' Parfit reaches is:

For any possible population of at least ten billion people, all with a very high quality of life, there must be some much larger imaginable population whose

1 Brian Barry, Justice as Impartiality (Oxford, 1995), p. 225, emphasis suppressed.

2 John Stuart Mill, 'Utilitarianism', Essays on Ethics, Religion and Society, ed. J. M. Robson, Collected Works of John Stuart Mill, $\mathrm{x}$ (Toronto, 1969), p. 257. For analysis of the role that equality plays in Bentham's political thought, see Frederick Rosen, Classical Utilitarianism from Hume to Mill (London, 2003), chs. 12-13; Rosen, Jeremy Bentham and Representative Democracy (Oxford, 1983), ch. 10; Gerald J. Postema, 'Bentham's Equality-Sensitive Utilitarianism', Utilitas 10 (1998); H. L. A. Hart 'Natural Rights: Bentham and John Stuart Mill', in Essays on Bentham: Studies in Jurisprudence and Political Theory (Oxford, 1982); David J. Crossley, 'Utilitarianism, Rights and Equality', Utilitas 2 (1990).

3 Will Kymlicka, Contemporary Political Philosophy: An Introduction (Oxford, 1991), p. 31, emphasis added.

4 Ibid., p. 32. See John Rawls, A Theory of Justice (Oxford, 1999), pp. 19-24. 
existence, if other things are equal, would be better, even though its members have lives that are barely worth living. ${ }^{5}$

As Kymlicka points out, such an argument could not spring from a commitment to 'equality of interests', because only the welfare of those already alive would be considered relevant to any moral assessment. Put bluntly, "non-existent people do not have moral claims-we do not have a moral duty to bring them into the world.' ${ }^{\prime 6}$ It would seem, then, that Parfit's argument could be justified solely through reference to a teleological account of utilitarianism, one that prioritizes a certain vision of the good, such as 'maximum quantity of overall happiness experienced'. In order to satisfy this good, it would clearly be preferable to increase population as much as is expedient, since what matters is the total amount of happiness experienced and not who is experiencing it or at what level.

The justificatory foundations of utilitarian arguments are not always this clear-cut, as the case of John Stuart Mill illustrates. There is no doubt that when pressed on the issue of egalitarian foundations, Mill was quite explicit, suggesting that utilitarianism was

A mere form of words without rational signification, unless one person's happiness, supposed in equal degree (with proper allowance made for kind), is counted for exactly as much as another's. Those conditions being supplied, Bentham's dictum 'everybody to count for one, nobody for more than one', might be written under the principle as an explanatory commentary. ${ }^{7}$

Directly confronting the charge of Herbert Spencer, that utilitarianism is self-contradictory since it presupposes an equal 'right' to happiness, Mill states that such an egalitarian commitment is not a presupposition; not a premise needful to support the principle of utility, but the very principle itself'. 8

Mill's utilitarianism appears, then, to have the same egalitarian foundation as Bentham's. Yet, as Kymlicka notes, advocates of utilitarianism frequently advance arguments that rely on a 'tacit mixing of the two justifications' ${ }^{9}$ and this is a prominent issue in Mill's political thought. For example, The Subjection of Women contains an argument for sexual equality, which, whilst seemingly relying on an egalitarian foundation, often grasps for wider teleological justifications. Mill claims that the unequal position of women in society is, on the one hand 'wrong in itself' and, on the other, 'one of the chief hindrances to human

\footnotetext{
5 Derek Parfit, Reasons and Persons (Oxford, 1984), p. 388.

${ }^{6}$ Kymlicka, p. 32.

7 Mill, 'Utilitarianism', $C W \times$ x. 257.

8 Ibid., p. 258.

9 Kymlicka, p. 35.
} 
improvement'. ${ }^{10}$ Whilst there is no necessary contradiction between the two claims, as both could happen to be true, it would seem that only one could provide a (non-question-begging) normative foundation. If individuals are to be treated equally because equality is a fundamental norm, then the human progress that accompanies it is of secondary importance, whilst if it is human progress that ultimately matters, the equality necessary for it is of merely instrumental value.

This justificatory problem becomes particularly acute when examining the classical utilitarian defence of ethical impartiality. Whereas Bentham's commitment to impartiality is logically entailed by his idea of equality, Mill's writings on the issue are far more ambiguous. Indeed, it is unclear whether or not it is ultimately justified as a corollary of a foundational egalitarianism or by a wider teleological ethic. For instance, in chapter 5 of Utilitarianism, he describes impartiality as the 'first of judicial virtues', a 'necessary condition of the fulfilment of the other obligations of justice'. ${ }^{11}$ However, he also states that acting impartially 'does not seem to be regarded as a duty in itself, but rather as instrumental to some other duty'. ${ }^{12}$ The question this begs is clear: is the impartial treatment of individuals a foundational component of Mill's utilitarianism (as it is for Bentham), or is it only important for 'instrumental' utilitarian reasons? This problem is not unique to Mill and is prominent in the most notorious utilitarian account of impartiality: that offered by William Godwin.

II

The most widely discussed aspect of William Godwin's utilitarianism ${ }^{13}$ is its extreme nature, ${ }^{14}$ which is most evident in his argument for

10 Mill, 'The Subjection of Women', Essays on Equality, Law, and Education, ed. J. M. Robson, Collected Works of John Stuart Mill, xxi (Toronto, 1984), p. 261.

11 Mill, 'Utilitarianism', $C W$ x. 257, emphasis added.

12 Ibid., p. 243.

13 I am obviously working on the assumption that Godwin is best described as a utilitarian thinker, which is a somewhat contentious claim. Traditional accounts of the growth of utilitarian thought (e.g. Leslie Stephen, The English Utilitarians (London, 1900); Elié Halevy, The Growth of Philosophic Radicalism (London, 1952); John Plamenatz, The English Utilitarians (Oxford, 1958)) and more recent accounts of Godwin's thought (e.g. John P. Clark, The Philosophical Anarchism of William Godwin, (Princeton, 1977); Don Locke, A Fantasy of Reason: The Life and Thought of William Godwin (London, 1980); Peter H. Marshall, William Godwin (London, 1984)) do consider his ethical scheme to be utilitarian. This has, however, been disputed. Mark Philp argues in Godwin's Political Justice (Ithaca, 1986) that Godwin's political thought is better described as 'perfectionist' (see esp. ch. 4) - though he does concede that the label utilitarian becomes appropriate as early as the second edition of Political Justice in 1795 (p. 157). Philp's argument is largely predicated on the controversial claim that utilitarianism cannot 'provide an account of the moral position which Godwin believed he was advancing' because his 'version is just too sophisticated for this period' (p. 84).

14 The fact that Shelly Kagan - who suggests that it is morally reprehensible to attend the cinema when one could be more effectively contributing to the greater good - cites 
impartiality, advanced through consideration of a notorious ethical dilemma, subsequently dubbed the 'famous fire cause'. It originally appeared in his controversial Enquiry Concerning Political Justice, first published in 1793. Godwin altered some of the minor details of the dilemma in two subsequent editions of the text - in 1795 and 1797 but his argument remained the same in each. Indeed, though scholars often place emphasis on the later modifications of his views, Godwin never substantially altered the basic thrust of his argument. ${ }^{15}$

In his infamous scenario, two individuals are trapped together inside a burning building with only enough time to rescue one. The two people in question are the seventeenth-century French philosopher Archbishop Fénelon and his valet. ${ }^{16}$ Godwin argues that justice demands the rescue of Fénelon at the expense of the valet, on the grounds that

That life ought to be preferred which will be most conducive to the general good. In saving the life of Fénelon, suppose at the moment he conceived the project of his immortal Telemachus, I should have been promoting the benefit of thousands who have been cured by the perusal of that work of some error, vice and consequent unhappiness. Nay, my benefit would extend further than this; for every individual, thus cured, has become a better member of society, and has contributed in his turn to the happiness, information and improvement of others. Suppose I had been myself the valet; I ought to have chosen to die, rather than Fénelon should have died.... Suppose the valet had been my brother, my father or my benefactor. This would not alter the truth of the proposition ...

Godwin as an 'extremist' is telling in this respect: Kagan, The Limits of Morality (Oxford, 1989), pp. 1-2, 10.

${ }^{15}$ It is often implied (see, for example, Locke, ch. 16) that following the death of his wife Mary Wollstonecraft and intense criticism from both enemies and former friends, Godwin recanted his commitment to impartiality and rejected his argument in the 'famous fire cause'. Certainly, he did bemoan his inattention to the importance of feeling, in both his Memoirs of Wollstonecraft (1798) and the preface to his novel St. Leon (1799). He even composed a 'memorandum', intended to be the first part of a book on 'first principles' of morality, that suggested high regard for partial, 'domestic affections'. Peter Singer, Leslie Cannold, and Helga Kuhse have regarded such revisions as leaving only a 'muted impartialism' ('William Godwin and the Defense of Impartialist Ethics', Utilitas 7 (1995), p. 85). However, the lengthy treatment of the subject in Godwin's 'Thoughts Occasioned by the Perusal of Dr. Parr's Spital Sermon ...' (Uncollected Writings by William Godwin (1785-1822), ed. Jack. W. Marken and Burton R. Pollin (Gainsville, Fl., 1968) hereafter referred to as 'Reply to Parr'), published in 1801, suggests otherwise. Herein, although Godwin reprints the extracts from both the Memoirs and St. Leon, and continues to laud domestic affections, his central arguments retain a robust utilitarian commitment to impartiality. 'Parental and filial affection' are important as they enable individuals to cultivate a virtuous personality and because there is simply more chance of generating utility through interactions with those in close proximity (pp. 316-17). Tellingly, he concludes that affective ties 'are liable to excess' and must have 'rigorous limits assigned': 'I must take care not so to love, or so to obey my love to my parent or child, as to intrench upon an important and paramount public good' (p. 321).

16 Or his chambermaid, depending on which edition of Political Justice is consulted. The gender of the individual in question changes over the course of the three editions and alternative explanations for these changes have been advanced. A rundown of scholarly speculation on the matter can be found in Singer et al., 'William Godwin', p. 71. 
justice, pure unadulterated justice, would still have preferred that which was most valuable. ${ }^{17}$

So, in such situations, we ought to rescue the individual who will do most for the 'general good' and this is the case even if it entails the sacrifice of either our own life or that of our nearest and dearest.

Anticipating the obvious objection that one should save the valet simply because he is my parent, Godwin asks

What magic is there in the pronoun 'my', that should justify us in overturning the decisions of impartial truth? My brother or my father may be a fool or a profligate, malicious, lying or dishonest. If they be, of what consequence is it that they are mine? ${ }^{18}$

Upon first reading, the meaning of these passages seems quite clear: Godwin apparently suggests that in such a perilous situation, justice requires affective relationships to be ignored for the sake of the overall good. For all that matters when morally evaluating this action are the consequences of the agent's actions. ${ }^{19}$ It is therefore proper to rescue somebody who will contribute to the 'happiness, information and improvement of others' rather than a 'fool or a profligate'. Yet, the consequences of Godwin's argument are even more far-reaching than the sacrifice of a 'bad' parent; indeed, one's parent could be an affable, well-meaning sort, yet such factors would still be irrelevant if they were of little social 'worth' when compared to Fénelon. It is unsurprising then that Godwin stands accused of advancing a ruthless form of act-utilitarianism, whereby each act is considered just, purely to the extent that it generates utility. ${ }^{20}$

In the following passages, Godwin goes on to consider (and reject) several arguments for alternative courses of action. He assesses the claim that an individual should rescue their parent, because of a debt

17 William Godwin, Enquiry Concerning Political Justice and its Influence on Morals and Happiness, ed. F. E. L. Priestly (Toronto, 1946), vol. 1, pp. 127-8.

18 Ibid., p. 128.

19 In Political Justice, Godwin does attach importance to individual motivations, defining a virtuous action as 'any action ... of an intelligent being proceeding from kind and benevolent intention and having a tendency to contribute to general happiness' (p. 149). However, in the 'Reply to Parr' he makes clear that, although important, intentions cannot be the 'criterion' of virtue: 'when we proceed to ascertain whether our actions are entitled to the name of virtue, this can only be done by examining into their effects, by bringing them to a standard, and comparing them with a criterion', which is 'utility' (pp. 318-19).

${ }_{20}$ Indeed, it is undoubtedly because of this interpretation that Godwin remains so often invoked in contemporary discussions of impartiality. As Don Locke notes, the 'famous fire cause' 'is just the sort of example often invoked as providing an exception to, perhaps even a refutation of utilitarian principles' (p. 173). Or as Brian Barry puts it 'for antiutilitarians, if Godwin had not existed he would have to have been invented' (Justice as Impartiality, p. 225). 
owed for assistance 'in the helplessness of infancy'. ${ }^{21}$ Godwin's response is that this is mere gratitude and is therefore 'no part of either justice or virtue'. ${ }^{22}$ This is because gratitude is retrospective, as Godwin sees it, 'a sentiment of preference which I entertain towards another, upon the grounds of my having been the subject of his benefits'. ${ }^{23}$ But what if an individual is unaware of Fénelon's value to society yet has ample evidence of the talents and potential of his kin? Godwin's answer to this is that it is a mere excuse, explained by 'the imperfection of human nature': 'it may serve as an apology for my error', he writes, 'but can never change error into truth'. ${ }^{24}$

\section{III}

Godwin's utilitarianism thus seems unflinchingly consequentialist and is almost universally presented in such terms. For example, Marcia Baron concludes that

Godwin's extreme views ... turn out to be based not primarily on a conception of impartiality or on moral notions which motivate it, such as fairness or equality. They are based, rather, on his belief that we have a duty to do everything possible to promote the general weal - together with a rather crude notion of just what it is to do so. ${ }^{25}$

Baron's view would clearly place Godwin amongst those who defend utilitarianism on teleological grounds. Rescuing Fénelon would contribute more to the 'general weal' than rescuing one's mother, father or whomever, and thus it is the morally right action. Also in the quoted passage, Baron unequivocally states that Godwin's arguments have no egalitarian basis.

There is certainly plenty of additional evidence throughout Political Justice in support of Baron's interpretation and Godwin frequently uses what appears to be a very blunt form of consequentialist reasoning. For example, turning his attention to property rights, he claims that an individual can have no legitimate ownership over goods that could be more beneficially utilized by another. Thus, if 'my neighbour is in want of ten pounds that I can spare ... unless it can be shown that the money can be more beneficially employed, his right is as complete ... as if he had my bond in his possession, or had supplied me with goods to the amount'. ${ }^{26}$ He has a similar attitude towards

21 Godwin, Political Justice, vol. 1, p. 128.

22 Ibid., p. 129.

23 Ibid.

24 Ibid., p. 130.

25 Marcia Baron, 'Impartiality and Friendship', Ethics 101.4 (1991), p. 842, emphasis added.

26 Godwin, Political Justice, vol. 1, p. 135. 
suicide. Whilst he doubts that such an act could ever benefit society, he suggests that in common with every branch of morality, it is a topic of calculation, as to the balance of good and evil to result from its employment in any individual instance'. ${ }^{27}$ Even the crucial commitment to sincerity that runs throughout his political thought appears to have a consequentialist justification. Thus the only reason for keeping promises is that doing so 'tends to the welfare of intelligent beings', ${ }^{28}$ for any 'obligation of sincerity', he contends, is dependent on 'the indefeasible benefit annexed to its observance'. ${ }^{29}$ These arguments, along with his declaration that the criterion of justice is the influence my conduct will have on the stock of the general good', ${ }^{30}$ seem to vindicate Baron's teleological interpretation of Godwin's argument.

Although this vision of Godwin as a strict act-utilitarian is a familiar one - and despite the evidence in support of such a vision - there are problems with Baron's analysis. Her argument, that Godwin's defence of impartiality has no moral commitments prior to maximizing the general good, only holds if it is accepted that all Godwin is interested in is the maximization of happiness in the Parfitian, teleological sense discussed earlier (which is what Baron must mean by 'general weal'). Yet there is significant evidence to suggest that Godwin values more than merely the maximization of overall happiness for its own sake, which, in turn, suggests that his defence of impartiality stems from a foundational principle that is not teleological.

Indeed, Godwin's commitment to impartiality can be interpreted as deriving from the fundamental commitment to equality that often grounds utilitarian arguments. Such a claim seems admittedly problematic when considering the 'famous fire cause', because it appears to be a striking example of unequal treatment. It seems quite strange, perhaps even contradictory, to consider an argument for preserving one individual at the expense of another as emerging from a basic commitment to equality. However, despite the obvious disparity in outcomes, the process can still be regarded as a fundamentally egalitarian one. This is because the traditional, Benthamite utilitarian conception of equality is quite consistent with Godwin's argument for preserving Fénelon. As noted earlier, for Bentham, the equal treatment of individuals entails the equal counting of their individual happiness

29 Ibid., p. 212.

30 Ibid., p. 197. 
in the utilitarian calculus. ${ }^{31}$ This connection of equal treatment and utilitarian calculation has also been invoked by Sidgwick and Peter Singer. ${ }^{32}$ Godwin's defence of impartiality can accordingly be regarded as thoroughly egalitarian, since his approach counts each individual's (idealized) happiness equally, before reaching the conclusion that rescuing Fénelon is the morally correct action. Such an interpretation is endorsed by Brian Barry, who argues that Godwin moves 'quite explicitly' from 'the claim that impartiality requires the equal consideration of interests to the conclusion that impartiality entails the summation of interests. ${ }^{33}$

This reading, that is, one that demonstrates that Godwin does care about equality - and further, that this manifests itself in the 'famous fire cause' - would seem to undermine Baron's analysis. But this is still not the whole story. What emerges from careful analysis of the entire chapter that details the scenario, 'Of Justice', is Godwin's commitment to a more complex justification than is traditionally supposed. Indeed, when justifying the preservation of Fénelon at the expense of a loved one, Godwin offers two 'grounds of preference'. Furthermore, although both grounds are reliant on fundamental egalitarian commitments, these commitments appear to embody two different, indeed conflicting, notions of equality. Establishing whether or not the two rival conceptions of equality can form a coherent argument, or which of the two has a primary justificatory role, depends on interpreting some ambiguous aspects of the text.

\section{IV}

The argument for keeping Fénelon alive is not presented by Godwin himself in the straightforwardly consequentialist terms employed by subsequent commentators. His claim that the 'life ought to be preferred which will be most conducive to the general good' is actually introduced as a second reason for preserving Fénelon - indeed as 'another ground of

31 This interpretation of Bentham's political theory has been recently challenged by Rosen, who claims that it demands not aggregative happiness but 'the provision of an equal quantity of happiness to all concerned' (Classical Utilitarianism, p. 229).

${ }_{32}$ In his introduction to Practical Ethics (Oxford, 1979), Singer writes: 'Imagine that I am trying to decide between two possible courses of action .... Suppose I then begin to think ethically, to the extent of recognizing that my own interests cannot count for more, simply because they are my own, than the interests of others. In place of my own interests, I now have to take account of the interests of all those affected by my decision. This requires me to weigh up all these interests and adopt the course of action most likely to maximize the interests of those affected. Thus I must choose the course of action which has the best consequences, on balance, for all affected. This is a form of utilitarianism' (p. 12). Cf. Sidgwick, The Method of Ethics (London, 1907).

${ }_{33}$ Barry, Justice as Impartiality, p. 225. 
preference'. ${ }^{34}$ Prior to championing the consequentialist case in favour of rescuing the archbishop, Godwin offers a different argument.

The chapter 'Of Justice' begins with Godwin defining justice as the 'impartial treatment of every man in matters that relate to his happiness'. ${ }^{35} \mathrm{He}$ then considers practical applications of this principle, first assessing the classic Christian maxim 'that we should love our neighbour as ourselves'. He argues that despite 'possessing considerable merit as a popular principle', such a moral rule must ultimately be rejected, on the grounds that it is not modelled with the strictness of philosophical accuracy'. ${ }^{36}$ This is a strangely phrased and revealing response. A typical utilitarian assessment of moral rules such as 'love thy neighbour as yourself' would stress their contingency: they may be important moral strictures if it can be established that they generate overall utility. Their adoption as moral rules depends upon this and they should not be regarded as holding any intrinsic value. Given his rejection of moral practices such as gratitude and promisekeeping on consequentialist grounds, this would seem to be the line of argument that we would expect Godwin to offer with regard to 'love thy neighbour'. Indeed, he does gesture towards this type of response by acknowledging the 'merit' of this particular moral rule as a 'popular principle'. The implication is that we should love our neighbours as ourselves for as long as this practice is conducive to the general good. However, the reason that Godwin actually provides to further explain the 'philosophical inaccuracy' of this principle is far removed from this (or any) standard utilitarian objection.

Godwin rejects the 'love thy neighbour as ourselves' command on the following grounds:

In a loose and very general view I and my neighbour are both of us men; and of consequence entitled to equal attention. But in reality, it is probable that one of us is a being of more worth and importance than the other. ${ }^{37}$

So, we should not love our neighbours as much as ourselves, as this would ignore a differential in our respective 'worth and importance'. He then explains the way in which 'worth' is to be measured: 'A man is worth more than a beast; because, being possessed of higher faculties, he is capable of a more refined and genuine happiness. ${ }^{38} \mathrm{An}$

${ }^{34}$ Godwin, Political Justice, vol. 1, p. 127.

35 Ibid., p. 126. The basis of this equality is Godwin's claim that humans are 'partakers of a common nature' (p. 146). However, he also suggests that 'justice has relation to beings endowed with perception, and capable of pleasure and pain' (p. 146), which would seem to extend the boundaries of his moral universe to include (at least some) non-human animals. Indeed, his only reason for declaring that 'a man is of more worth than a beast' is that 'he is capable of a more refined and genuine happiness' (p. 126).

${ }^{36}$ Ibid., p. 126.

37 Ibid., p. 126, emphasis added.

38 Ibid. 
agent's worth is, then, measured by their capacity for experiencing a qualitatively superior level of happiness. It is on this basis that Godwin then concludes that:

In the same manner the illustrious archbishop of Cambray was of more worth and importance than his valet, and there are few of us that would hesitate to pronounce, if his palace were in flames, and the life of only one of them could be preserved, which of the two ought to be preferred. ${ }^{39}$

So this first 'ground of preference' is that Fénelon is 'of more worth and importance', as he is capable of 'a more refined and genuine happiness' than his valet.

On the face of it, the recognition of an individual's worth seems entirely consistent with Godwin's consequentialist reasoning. Clearly one could argue that rescuing the most worthy individual is the right thing to do because it would have desirable consequences. Such an argument could run along a number of different lines. Fénelon could be of 'more worth and importance' because he will contribute more to the happiness of the rest of the population. Alternatively, it could be argued, simply using Godwin's definition of 'worth', that Fénelon should be saved because he is capable of experiencing a qualitatively higher happiness, which will, in turn, increase total utility.

There is, however, a compelling reason to resist these consequentialist interpretations of this, first, worth-based argument. Crucially, Godwin is about to introduce the consequentialist case for rescuing Fénelon as 'another ground of preference', for consideration 'beside the private consideration of one of them being further removed from the state of a mere animal'. ${ }^{40}$ Thus, if we take Godwin literally and there is no reason not to - we must then accept that there are two distinct grounds upon which he is defending the rescue of Fénelon in favour of a less worthy individual. The second ground of preference, whether justified on an egalitarian or a teleological basis, is undoubtedly consequentialist. The first ground of preference thus cannot be - or at least, if it were, it would make absolutely no sense for him to draw such a clear distinction between different grounds of preference. It is therefore necessary to establish what possible non-consequentialist reason Godwin has to value the "worth and importance' of Fénelon.

The nature of Godwin's first ground of preference can be explained by shifting the interpretive focus onto his very specific definition

39 Ibid., pp. 126-7.

40 Ibid., p. 127, emphasis added. 
of equality, which is elucidated in the following chapter of Political Justice, 'Of the Equality of Mankind'. Herein, Godwin makes it plain from the outset that, 'the principles of justice, as explained in the preceding chapter, proceed upon the assumption of the equality of mankind'. ${ }^{41}$ This declaration clearly demonstrates the egalitarian roots of all his previous arguments concerning justice, including the 'famous fire cause'.

The chapter begins with Godwin following Rousseau's differentiation of two types of potential inequality: 'physical' and 'moral'. ${ }^{42}$ Though adamant that the basis of neither inequality is natural or perennial, Godwin does go on to defend 'one species of inequality'. This 'species' is the belief that 'the treatment to which men are entitled is to be measured by their merits and their virtues'. ${ }^{43}$ Godwin then defends this inequality, that of rewarding meritorious or virtuous individuals, on two different grounds. First, there is a typical consequentialist justification, which claims that, "that country would not be the seat of wisdom and reason where the benefactor of his species was regarded with no greater degree of complacence than their enemy'. ${ }^{4}$

However, Godwin's second justification is egalitarian. He suggests that the recognition of moral worth and the corresponding inequality of treatment it involves, 'In reality, so far from being adverse to equality in any tenable sense, is friendly to it, and is accordingly known by the appellation of equity, a term derived from the same origin. ${ }^{45}$ The recognition of virtuous actions is not, then, justified by Godwin merely on consequentialist grounds, but rather because it is part of what it means to treat individuals in a strictly equal manner. If this is the case, and we accept his assertion that the demands of justice 'proceed upon' the assumption of equality, it seems more than reasonable to propose that this notion of reward plays a role in the case for preserving Fénelon's life. Evaluating an individual's worth is, by definition, a retrospective activity and when a consequentialist justification is unavailable, individual virtue becomes valuable solely for its own sake.

If Fénelon's moral character is the reason for his rescue, and the grounds are not consequentialist, then a principle of desert would seem to be the only possible explanation. This interpretation is at first hard

${ }^{41}$ Ibid., p. 143, emphasis added.

42 Ibid., J.-J. Rousseau, 'A Discourse on the Origin of Inequality', The Social Contract and Discourses, ed. G. D. H. Cole (London, 1993) p. 49.

${ }^{43}$ Godwin, Political Justice, vol. 1, p. 147.

44 Ibid.

${ }^{45}$ Ibid. This idea - that equality means the differential treatment of individuals according to their merits or virtues - can be traced at least as far back as Aristotle's Nicomachean Ethics, Book. V. 
to swallow because it seems to conflict with Godwin's utilitarianism, which is, as shown earlier, hostile to any retrospective moral evaluation for non-consequentialist reasons. ${ }^{46}$ But it is consistent with Godwin's key claim that the recognition of individual merit or virtue (and corresponding inequality of treatment) is part of the meaning of equality and that justice 'proceeds upon' this equality. Curiously, within her discussion of the 'famous fire cause', Marcia Baron recognizes this ambiguity, but ignores any significant implications it might have for determining the nature of Godwin's argument. In a footnote, she cautions that 'his position is not as unambiguous as it may sound' because 'at times his view seems to be that we are obliged to help the first needy and deserving person that comes our way'. ${ }^{47}$ In the very next footnote, she admits 'a tension in his theory between the claim that we should optimize and the claim that we should reward those who have optimized', concluding that 'while these need not be inconsistent, some work is needed to show how they cohere, if, indeed, they do'. ${ }^{48}$ Presumably, Baron believes that it is possible for the 'tension' between the two rival arguments to be resolved coherently because she believes them to be grounded in the same justificatory principle. That she thinks this is evident from her subsequent pronouncement that Godwin is only interested in the 'general weal'. At no point, however, does she mention his separation of the two arguments as distinct 'grounds of preference', which, as shown, indicates the presence of two separate justificatory principles.

Baron's assumption of justificatory coherence is, to an extent, understandable, as later in the chapter Godwin does appear to run the two arguments together, notably when listing the reasons for not rescuing one's parent. He argues that even if your parent has bestowed a 'voluntary benefit' on you, this in itself is not enough to justify their preservation:

I and another man cannot both be right in preferring our respective benefactors, for my benefactor cannot be at the same time both better and worse than his neighbour. My benefactor ought to be esteemed, not because he bestowed a benefit upon me, but because he bestowed it on a human being. ${ }^{49}$

He then asserts that the benefactor's 'desert will be in exact proportion to the degree in which that human being was worthy of the distinction

\footnotetext{
46 There clearly remains a utilitarian element to Godwin's concept of desert. Though the first ground of preference is a non-consequentialist recognition of Fénelon's past virtuous behaviour, it is his past maximization of utility (Godwin's measure of virtue) that makes him a deserving individual in the first place.

${ }_{47}$ Baron, 'Impartiality and Friendship', p. 841, n. 14. The claim that Godwin believes we are obliged to help the first 'needy' person who 'comes our way' seems unfounded.

48 Ibid., n. 15.

49 Godwin, Political Justice, vol. 1, p. 129.
} 
conferred'. ${ }^{50}$ Leaving aside the additional argument advanced - that the worth of one individual depends on the worth of the recipient of that individual's voluntary benefit - it is not at all clear what Godwin is now doing with 'desert'. He seems here to be using it as a secondary principle in a consequentialist scheme, as the following passage seems to indicate. Considering the argument that rescuing our parents will promote general utility, Godwin responds by asking

Is the general good promoted by falsehood, by treating a man of one degree of worth as if he had ten times that worth? or as if he were in any degree different from what he really is? Would not the most beneficial consequences result from a different plan; from my constantly and carefully enquiring into the deserts of all those with whom I am connected, and from their being sure, after a certain allowance for the fallibility of human judgement, of being treated by me exactly as they deserved? Who can describe the benefits that would result from such a plan of conduct, if universally adopted? ${ }^{51}$

There is no doubt that in this passage Godwin justifies the recognition of desert (and thus the preservation of Fénelon) on consequentialist grounds. To complicate matters further, Godwin declares that, 'Every view of the subject brings us back to the consideration of my neighbour's moral worth, and his importance to the general weal, as the only standard to determine the treatment to which he is entitled. ${ }^{52}$ The entire meaning of this seemingly pivotal passage, and perhaps the whole of Godwin's argument, hinges on how we are to interpret his use of the word 'and'. Is Godwin using 'and' to refer back to the two distinct reasons originally advanced for rescuing Fénelon, on the one hand, 'moral worth', and on the other, 'the general good'? Or does the 'and' perhaps signal that the two justifications are necessarily connected in some way? That he originally introduced two 'grounds of preference' suggests an affirmative answer to the former question, with 'and' acting to distinguish between them. Yet, in this passage he describes what appear to be two different justifications as the 'only standard', confusing matters even further.

If it is accepted that Godwin provides two distinct arguments for preserving Fénelon - one based on rewarding him for virtuous actions and the other for the benefits his existence will afford society - there still remains the problem of justificatory primacy within Godwin's argument. The reason this problem arises is the seemingly irreconcilable conflict between utilitarianism and a nonconsequentialist desert principle. What Fénelon has done in the past is - from a utilitarian perspective - only contingently related to what

\footnotetext{
50 Ibid., emphasis added.

51 Ibid., pp. 130-1, emphasis added.

52 Ibid., p. 129, emphasis added.
} 
he will do in the future. The question that emerges, then, is what matters most to Godwin: the principle of rewarding those who maximize utility or the principle of maximizing utility? There seems no easy way of reconciling these two contradictory principles and therefore no straightforward solution to this apparent justificatory ambiguity. It is, however, perhaps significant that this ambiguity is also present in Mill's account of impartiality in Utilitarianism. Mill notes that although acting impartially has different meanings in different spheres, there are several cases in which it means 'being solely influenced by desert'. ${ }^{53}$ Furthermore, he describes the 'duty to do to each according to his deserts', as 'the highest abstract standard of social and distributive justice; towards which all institutions, and the efforts of all virtuous citizens, should be made in the utmost possible degree to converge'. ${ }^{54}$ Despite such views, Mill is keen to point out that this duty

rests upon a still deeper foundation, being a direct emanation from the first principle of morals, and not a mere logical corollary from secondary or derivative doctrines. It is involved in the very meaning of Utility, or the Greatest Happiness Principle. ${ }^{55}$

Thus, desert seems ultimately to be nothing more than a 'secondary principle' for Mill. ${ }^{56}$ But he fails to demonstrate exactly how the moral requirement to recognize deserving individuals 'emanates' from the utility principle. It is then immediately following this discussion of impartiality and desert that Mill cites Bentham's dictum as the principle underpinning utilitarianism. The difficulty all of this raises should be clear enough. Mill first suggests that impartiality sometimes demands the recognition of individual desert claims. Then, he suggests that as important as desert is, its justification is bound up in the 'very meaning of Utility', which, in turn, has an egalitarian foundational principle. But the conceptual relationship between 'desert', 'utility' and 'equality' is hardly a self-evident one and Mill's reluctance to spell them out arguably points to real tensions within his utilitarianism - tensions that seem paralleled in Godwin's account.

The appearance of moral worth in the specific context of the 'famous fire cause' can perhaps be explained as a manifestation of Godwin's debt to the tradition of Rational Dissent, which played such a formative role in his intellectual development. On such a reading, the choice to

${ }^{53}$ Mill, 'Utilitarianism', $C W \mathrm{x}$. 243. Mill distinguishes between cases that demand the recognition of desert claims and those that demonstrate 'consideration for the public interest' (p. 243).

54 Ibid., p. 257. Elsewhere in this chapter, Mill describes recognizing desert as 'perhaps, the clearest and most emphatic form in which the idea of justice is conceived by the general mind' (p. 242).

${ }_{55}$ Ibid., p. 257.

${ }^{56}$ Roger Crisp, Mill on Utilitarianism (London, 1997), pp. 175-6. 
preserve the archbishop would be made by an all-knowing rational deity concerned with issues other than mere consequences. ${ }^{57}$ It may be highly significant, then, that Godwin stresses the need to 'put ourselves in the place of an impartial spectator, of an angelic nature... beholding us from an elevated station'. ${ }^{58}$ Another possible explanation lies, ironically, in the political writings of Fénelon himself. Fénelon's moral hierarchy prizes a form of action above all others: one in which neither 'fear of punishment' nor 'hope of reward' provides any motivation for the agent. ${ }^{59}$ Such an ideal befits Godwin's contempt for external interference and can perhaps explain how notions of moral worth are embedded in the 'famous fire cause' and his account of human equality.

\section{VI}

There remains a final problem raised by Godwin's first, worthbased ground of preference: how does it fit within his overall ethical framework? The problem of coherence between Godwin's argument for rewarding virtue and the rest of his political thought emerges because of the critical attitude he displays in Political Justice towards desert as a moral principle: indeed, at one point arguing that 'there is no such thing as desert'. ${ }^{60}$ Despite his suggestion that the recognition of merit and virtue is justifiable on both egalitarian and consequentialist grounds, he quite explicitly rejects it as a basis for both distributive and retributive justice. As far as the distributive sphere is concerned, he notes that 'it has sometimes been alleged, as an argument against the equal rights of men ... "that the merits of men are different, and ought to be differently rewarded" ${ }^{61}$ He then suggests that although this proposition is in some sense 'true', it should not be applied to property. ${ }^{62} \mathrm{He}$ provides a similarly uncompromising rejection of

57 I am grateful to Alan Ryan for this suggestion. For a detailed discussion of Godwin's debt to Rational Dissent, see Philp, ch. 1.

58 Godwin, Political Justice, vol. 1, p. 133 (emphasis added).

59 See Patrick Riley, 'Rousseau, Fénelon, and the Quarrel between the Ancients and the Moderns', The Cambridge Companion to Rousseau, ed. Patrick Riley (Cambridge, 2001), p. 80.

60 Ibid., vol. 2, p. 327. This remark is made in the context of Godwin's discussion of punishment, in which he embraces hard determinism, notoriously pronouncing that 'the assassin cannot help the murder he commits, any more than the dagger' since individuals are 'propelled to act by necessary causes and irresistible motives' (p. 324).

61 Godwin, Political Justice, vol. 2, pp. 428-9.

62 Ibid. Godwin is unequivocal on this point: " "If you show yourself deserving, you shall have the essence of a hundred times more food than you can eat, and a hundred more times more clothes than you can wear. You shall have a patent for taking away from others the means of a happy and respectable existence, and for consuming them in riotous and unmeaning extravagance." Is this the reward that ought to be offered to virtue, or that virtue should stoop to take?'. This attitude would seem to undermine Isaac Kramnick's 
retributive punishment, arguing that 'to punish' an individual 'for what is past and irrecoverable and for the consideration of that only, must be ranked among the most pernicious exhibitions of an untutored barbarism'. ${ }^{63}$ His more general point in both discussions is that the practice of 'conferring rewards' has a necessarily 'pernicious effect'. ${ }^{64}$ This presents an obvious problem: if desert is a 'pernicious' foundation upon which to ground questions of justice, why does Godwin invoke it to defend his proposition that we are obliged (by justice) to disregard affective relationships in order to preserve Fénelon?

A resolution to this problem lies in the nature of the 'famous fire cause' itself. In contemporary debates, political philosophers make much of the difference between 'first-order' and 'second-order' impartialist theories. ${ }^{65}$ First-order impartiality concerns the level of individual actions whereas second-order impartiality focuses on the rules or principles that ground a moral theory. The tendency in contemporary discussions is to regard Godwin's 'famous fire cause' as the epitome of first-order impartiality: the assumption is that he expects us to act in an impartial manner at all times, under any circumstances. In contrast, second-order impartialist moral theories require no such demanding behaviour and are thought able, not merely to accommodate but actually to endorse the affective relationships that Godwin appears proud to shun. There are, however, reasons to doubt whether Godwin's argument actually indicates (as universally supposed) a first-order impartialist theory rather than a second-order alternative.

Godwin's second-order credentials emerge once it is realized that no impartialist theory accords ethical priority to affective relationships under all circumstances. Brian Barry's second-order impartialist theory is a perfect example of this. Barry's theory is explicitly addressed to impartial moral principles rather than everyday impartial actions and can thus accommodate affective relationships. Yet, Barry concedes that

in truly exceptional circumstances, any second-order impartialist theory would ... have to reach the same conclusion as Godwin about the right thing to do in the 'famous fire cause'. It is an unavoidable implication of any set of moral norms that can be squared with second-order impartiality in any of

interpretation of Godwin as a proponent of meritocracy in Republicanism and Bourgeois Radicalism (Ithaca, 1990).

63 Godwin, Political Justice, vol. 2, p. 327.

64 Ibid., p. 322.

${ }^{65}$ For some discussions of 'two-level' impartialist moral theories, see Barry, Justice as Impartiality, chs. 8-9; and Susan Mendus, Impartiality in Moral and Political Philosophy (Oxford, 2002), ch. 2. 
its forms that people may be unlucky enough to find themselves in situations where doing the right thing entails great sacrifice. ${ }^{66}$

Barry then offers alternative scenarios in which sacrifice is the right thing to do - such as having your family kidnapped by terrorists and being told they will be killed unless you plant a bomb certain to kill thousands. ${ }^{67}$ In such circumstances, he suggests 'the right thing to do is refuse to plant the bomb' in spite of the consequences faced by one's family. ${ }^{68}$ His point, then, is that sometimes, when the stakes are high enough, even second-order impartialist theories will recommend that affective ties be disregarded. In spite of this Barry maintains that the 'famous fire cause' represents first-order impartiality and that, for Godwin, there is nothing 'to restrict the imperative to sacrifice your parent' to a particularly extreme case: 'in principle, even a slight advantage in total future utility' would swing the outcome either way. ${ }^{69}$ But this crucial claim is suspect, since, for Godwin, Fénelon's impending death is a situation of extreme moral emergency. ${ }^{70}$

The argument that Fénelon's life is of the utmost value may seem eccentric, but the principle behind the argument is no different from Barry's. Indeed, in Political Justice Godwin acknowledges the importance of "providing, in ordinary cases for my wife and children, my brothers and relations, before I provide for strangers' ${ }^{71}$ Crucially, the circumstances under which this partiality rule must be abandoned seem to be exactly the same as those supplied by Barry and other second-order impartialists: that partiality must be disregarded in 'cases of a higher order'. ${ }^{72}$ The only disagreement, then, between Barry and Godwin concerns the specifics of the case in question, the value of the life of Fénelon, which only Godwin views as of tremendous utility to society. ${ }^{73}$ There is no difference in principle between the two arguments.

66 Barry, Justice as Impartiality, p. 223.

67 Ibid., pp. 223-4.

68 Ibid., p. 224. See also Barry, 'Something in the Disputation not Unpleasant', Impartiality, Neutrality and Justice: Re-reading Brian Barry's 'Justice as Impartiality', ed. Paul Kelly (Edinburgh, 1998), pp. 248-55, for a restatement of his argument that second-order impartiality sanctions sacrifice under some circumstances.

69 Barry, Justice as Impartiality, p. 224.

70 Barry does acknowledge that Godwin offers a more sophisticated impartialist theory than is usually supposed. However, he traces this to alleged changes in position outlined in the 'Reply to Parr', maintaining that the 'original view' in Political Justice is firstorder impartialist (ibid., pp. 224-5). Thus Barry later restates the seemingly artificial distinction between Godwin's justification for preserving Fénelon and his own 'terrorist' alternative ('Something in the Disputation', p. 250).

${ }^{71}$ Godwin, Political Justice, vol. 1, pp. 131-2.

72 Ibid.

${ }^{73}$ Though Godwin did subsequently confess his regret for using Fénelon as his example, it is on the grounds that he 'did not take into mind the prejudices and habits of men', realizing later that 'the benefit to accrue from the writing of books is too remote an 
The 'famous fire cause' is therefore better construed as indicating Godwin's commitment to a second-order impartialist theory than to the first-order variant that is most often attributed to him.

This view of Godwin's argument has clear relevance to the justificatory issues discussed earlier. If the rescue of Fénelon is a special case and Godwin does not subscribe to the view that we should always abandon our affective ties for marginal increases in utility, then there is no necessary contradiction in his introduction of a justificatory principle, which he rejects as a basis for general moral matters such as punishment or the distribution of property. There is thus no necessary conflict between Godwin's invocation of Fénelon's moral worth as a reason for his rescue and the view that desert is a 'pernicious' moral principle.

\section{CONCLUSION}

This article has taken a rather tortuous path to reach an equivocal conclusion, one that stresses the ambiguities in Godwin's utilitarian case for the preservation of Fénelon at the expense of a loved one. It is therefore probably useful to summarize the key points once more. It began by noting that there are usually two types of justification available for a utilitarian argument: egalitarian and teleological. However, as the example of John Stuart Mill indicates, it is not always easy to identify which principle ultimately does the justificatory work. Turning to Godwin's utilitarianism, I outlined the flaws in the common teleological interpretation of his argument for impartiality, contained in the 'famous fire cause'.

However, whilst locating a Benthamite egalitarian basis in Godwin's conclusion seems initially plausible, this interpretation seems to ignore key aspects of the argument. Close attention to the text reveals that Godwin offers two reasons for preferring Fénelon. Moreover, these reasons are not only superficially separate and part of the same argument, but actually stem from distinct (indeed conflicting) philosophical foundations. Though the second reason Godwin gives is utilitarian (seemingly justified on egalitarian rather than teleological grounds), the first appears to suggest that Fénelon should be rescued as a reward for his being further removed from the state of an animal. The significance of this argument becomes clear when Godwin's writings on the meaning of equality are considered. For Godwin, the recognition of moral worth is defensible not only on the grounds that it is conducive to the general good, but also because it is part of what it means to

idea, to strike and fill the imagination' ('Reply to Parr', p. 331). He suggests that either Brutus or Napoleon Bonaparte would have made more felicitous choices for his example. 
treat individuals as equals. In the same manner as it is wrong to distribute love equally between oneself and one's neighbour, it is wrong to consider two people equally worthy of preservation in a situation of tragic choice. Godwin is, then, offering two arguments for preserving Fénelon, both of which stem from foundational commitments to equality. Moreover, these are not only different conceptions of equality, they are actually conflicting conceptions; and it is unclear which is ultimately foundational.

When it comes to assessing Godwin's argument for impartiality, moral philosophers are quick to condemn the 'absurdity' of the conclusion that he reaches. ${ }^{74}$ This is not particularly surprising. What is surprising is the scant attention paid to the philosophical foundations that justify and motivate this argument. If these foundations are as ambiguous as they seem to be, there is clearly a case for further investigation and grounds for taking Godwin seriously as one of the most complex and sophisticated of the early utilitarian thinkers. ${ }^{75}$

r.lamb@ex.ac.uk

${ }^{74}$ See, for example, Mendus, pp. 49-55.

75 I am very grateful to Lena Halldenius, Alan Ryan and Corinna Wagner for criticism and to Dario Castiglione for valuable advice on this article. I owe a particular debt to Iain Hampsher-Monk for comments on several earlier drafts as well as innumerable discussions of Godwinian matters. 